\title{
On the One Time I Lost My Virginity and the 3 Times I Gave It Away
}

\author{
Rayan Jamal
}

\begin{abstract}
In this poem, I examine the concept of virginity as a social construct by referencing situations where I was told it could be lost through simple everyday acts, such as riding a horse or inserting a tampon. Through examining such situations, I equate virginity with the mere act of penetration. In doing this, I establish that penetrative masturbation is a loss of virginity, thereby challenging the idea that virginity is something that can be either lost or given. I take the reader through four separate sexual or pseudo sexual experiences to establish a non-linear journey through navigating virginity. The poem ends with the revelation that through the act of masturbating with a dildo, my virginity became something I gave myself.
\end{abstract}

\section{Keywords}

virginity, masturbation, sexual experience, queer 
On the one time I lost my virginity and the 3 times I gave it away

Forward:

I was told I could lose my virginity by

Wearing a tampon

Riding a bicycle

Or a horse

Or a man

Or a dildo

Or fingers that wander

Meaning, virginity is less about sex

And more about a foreign object in the body

Less about sex and more about doors yanked open

The story goes,

The difference between sexual acts and sex

Is the penetration by a foreign object

The story goes,

There are graveyards empty of headstones

And full of honorary hymns

They phrased it "losing my virginity"

Because the process is singularly painful,

Always a theft,

Someone does the colonizing,

And I do the mourning

The story goes,

I lost my virginity once

And gave it away 3 times 
1. The Boy

He was fuckboy turn feelings boy

I was just curious

When I saw his penis,

My impulse screamed

POKE IT

Maybe that should have been the first sign

Because vagina was love at first-sight

It was ice cream on a hot summer day

It was ...

It was poet turn speechless

Okay okay, getting off track here, the boy

The boy was untrained fingers on guitar strings

I was bruise marks thought love-bites

He was satisfied consumer

I was swallowed dissociation and panic attacks

I mailed him this virginity dressed in unworn Eid clothes,

No tracking number,

Lost 


\section{The Tampon}

Impromptu instructional demonstration

Tampon in tea mug

"Look," my now lover says,

"it could absorb an ocean"

You haven't felt softness

until you've seen a tampon drenched in purple tea

and no apologies

Finally, bedroom turn bathroom turn wedding

Is it not wedding when the white turns red?

I feel the tampon travel, My vagina a void swallowing it whole

The string an only sign of its once existence

This V-card mailed to them who taught me All the Tampon tactics 
3. (Penetrative) Masturbation

My fingers, in diaspora all this time

Immigrating beyond the art of clitoral cumming

The pitter-patter of fingers

The anxious back-and-forth walk

My fingers, a tampon

A personal penis of sorts

I feel their choreography

A readapted Dabke,

This dance, usually performed in celebrations

Requiring repetitive patterned movement

All the weddings attended taught me its rhythm

My masturbation, a wedding

My fingers a revelation, a prophet's epiphany

This virginity a homecoming party

After years of displacement 
4. The Dildo

Purple, glorious, and nothing like a penis

Named her Dickety

Ety- Arabic for possessive

So entirely mine

Dickety, a tip-toe midnight snack

Quiet, patient, and alert

Tip-toe turn to midnight dance party

My vagina making wanted space,

Stretching, building, edging, climaxing

But see,

Dickety cuddled me many times

Before she held me in orgasm

Nothing about her was foreign object

Both of us masturbating the art of patient pleasure

My virginity a thank you card I gave myself

A prayer I did not ask of anyone

A joyous collapse into sleep 


\section{Author Biography}

Rayan is a self-described mosaic person. Their academic and activist backgrounds blend together to form somebody whose drive is to dig deeper, complicate things, and shy away from a black/ white dichotomy. In their MA in Media Production research, they managed to weave their graphic design and creative writing background into their newfound passion for theory. This resulted in the first step towards what became their driving force: a desire to bridge the gap between the academy and the public. 